\title{
АКАДЕМІЧНА ДОБРОЧЕСНІСТЬ ТА АНТИПЛАГІАТНА ЕКСПЕРТИЗА У ЛЬВІВСЬКОМУ НАЦІОНАЛЬНОМУ МЕДИЧНОМУ УНІВЕРСИТЕТІ ІМЕНІ ДАНИЛА ГАЛИЦЬКОГО: КЛЮЧОВІ ЗАСАДИ І МЕТОДОЛОГІЯ
}

\author{
A. R. Vergun, S. P. Yagelo, H. M. Stechak \\ Danylo Halytskyi Lviv National Medical University

\section{ACADEMIC INTEGRITY AND PLAGIARISM EXPERTISE AT DANYLO HALYTSKYI LVIV NATIONAL MEDICAL UNIVERSITY: KEY PRINCIPLES AND METHODOLOGY}

\begin{abstract}
Анотація. У статті розглянуто й охарактеризовано ключові засади, методологію та комплекс заходів щодо імплементації і забезпечення академічної доброчесності та високих професійних стандартів у Львівському національному медичному університеті імені Данила Галицького, запобігання порушенням академічної доброчесності; честі, гідності, взаємної поваги і довіри, забезпечення рівноправності та толерантності всіх учасників освітнього процесу шляхом дотримання принципів і загальноприйнятих норм щодо етичної поведінки, протидії академічному плагіату з урахуванням вимог Законів України «Про освіту», «Про вищу освіту», «Про авторське право і суміжні права», рекомендацій Асоціації європейських університетів щодо відкритого доступу до наукової інформації та інших міжнародних асоціацій. Антиплагіатна перевірка наукових (включаючи дисертації) та навчально-методичних праць в Інтернеті та репозитарії університету здійснюється методом шингл-розбивки тексту ліцензованим та вільнодоступним П3 “Unichek”, “Plagiarism Detector Pro”, “Viper”, “AntiPlagiarism.NET”, “AdvegoPlagiatus” (ми жодним чином не рекламуємо якогось конкретного провайдера цих послуг чи алгоритму здійснення експертизи) і є достатньо ефективною, відповідає вимогам академічної доброчесності щодо трансдисциплінарної цінності проблемно-орієнтованого знання, сприяє покращенню якості освіти, підвищенню продуктивності навчального процесу та дослідницької діяльності.
\end{abstract}

Ключові слова: академічна доброчесність; антиплагіатна перевірка наукових праць; програмне забезпечення.

Abstract. The article considers and describes the key principles, methodology and some measures of implementation and maintenance of academic integrity and high professional standards at Danylo Halytskyi Lviv National Medical University, prevention of academic integrity violations, honor, dignity, mutual respect and trust, ensuring of equality and tolerance of all educational process participants by adhering to the principles and generally accepted norms of ethical behavior, counteraction of academic plagiarism taking into account the Laws of Ukraine "On Education”, “On Higher Education”, “On copyright and related rights”, recommendations of the Association of European Universities on scientific open access information and other international associations. Anti-plagiarism verification of scientific (including dissertations) and educational-methodical works on the Internet and the University Repository is carried out by shingle-breaking of the text by licensed and free available software "Unichek", "Plagiarism Detector Pro", "Viper”, "AntiPlagiarism. NET", "AdvegoPlagiatus" (we do not advertise any particular provider of these services or the algorithm of expertise) and is sufficiently effective, meets of the academic integrity requirements for the transdisciplinary value of problem-oriented knowledge, improves the quality of education, productivity of the educational process and research.

Key words: academic integrity; plagiarism expertise of scientific works; software.

Вступ. Однією з ключових складових внутрішньої системи забезпечення якості освіти є університетська система забезпечення академічної доброчесності, яка визначає загальноприйняті світовою

(C) А. Р. Вергун, С. П. Ягело, Г. М. Стечак спільнотою стандарти здійснення освітньої та наукової діяльності здобувачами вищої освіти й співробітниками університету [1] і створює середовище нульової терпимості до плагіату, фальсифікацій [2, 5] та інших порушень етики академічних взаємо- 
відносин [2, 5, 6, 8]. Підвищення авторитетності диплома про здобуття освіти та конкурентоспроможності випускника на ринку праці можливе лише за умови надання освітніх послуг і набуття компетенцій із дотриманням принципів академічної доброчесності й етики академічних (зокрема наукових) взаємовідносин [5, 6], виключення можливості створення умов для отримання неконкурентних переваг здобувачам вищої освіти при навчанні та здійсненні наукових досліджень [1, 2, 6, 8]. Нездатність і небажання слідувати кращим світовим практикам в освітньо-науковій діяльності веде до порушень у виконанні професійних обов'язків [1, 2, 5], шкодить науковим процесам, погіршує відносини між членами університетської спільноти, підриває довіру до якості освіти і досліджень та їх авторитетності $[2,5,6]$, призводить до марної витрати зайвих ресурсів і може завдати втрати іміджу університету [1, 5, 6, 8].

Мета статті - охарактеризувати методологію, комплекс заходів у Львівському національному медичному університеті імені Данила Галицького щодо імплементації та забезпечення академічної доброчесності і високих професійних стандартів, запобігання порушенням академічної доброчесності, дотримання принципів та загальноприйнятих норм щодо етичної поведінки, протидії академічному плагіату.

Теоретична частина. У розділах Кодексу академічної етики Львівського національного медичного університету імені Данила Галицького [5] враховано вимоги базових документів (зі змінами та доповненнями): Законів України «Про освіту», «Про вищу освіту» [4], «Про наукову і науково-технічну діяльність», «Про авторське право і суміжні права» [1, 2, 6], на основі рекомендацій Асоціації європейських університетів щодо відкритого доступу до наукової інформації (2008 р.) [5, 8, 10, 11], міжнародних асоціацій IFLA, SPARC, LIBER, EiFL та ін. [1, 5, 10, 11]. Відповідно до ст. 32 Закону України «Про вищу освіту» [4], заклади вищої освіти (ЗВО) зобов'язані вживати заходів, включаючи запровадження відповідних новітніх технологій [8, 9, 12-14], для запобігання та виявлення академічного плагіату в наукових роботах наукових, науково-педагогічних, педагогічних, інших працівників і здобувачів вищої освіти та притягнення їх (при наявності порушень академічної етики, зокрема фальсифікації результатів наукових досліджень та академічного плагіату) до дисциплінарної відповідальності [5-8]. Кодекс академічної етики Львів- ського національного медичного університету імені Данила Галицького визначає основні поняття, завдання академічної доброчесності, регламентує основні засади організації та контролю [5].

Положення про комісію з питань етики та академічної доброчесності (далі - Положення) у Львівському національному медичному університеті імені Данила Галицького визначає процедуру розгляду справ щодо порушення Кодексу академічної етики та норм академічної доброчесності $[1,2,8]$ членами університетської спільноти, а також способи дисциплінарного впливу [5-7]. Члени комісії працюють на громадських засадах. Склад комісії затверджується наказом ректора. Строк повноважень комісії становить 1 рік з моменту затвердження її складу. До складу комісії входять: проректор 3 наукової роботи; відповідальний за антикорупцію в університеті; вчений секретар разових спеціалізованих вчених рад (відповідальний за діяльність разових спеціалізованих вчених рад з присудження ступеня доктора філософії); відповідальний за первинну технічну антиплагіатну перевірку наукових, навчально-методичних праць і дисертаційних матеріалів; секретар комісії з питань етики наукових досліджень, експериментальних розробок і наукових творів; відповідальні за планові наукові теми; науковий керівник Товариства молодих вчених; голова Комісії із забезпечення гендерної рівності та протидії дискримінації; завідувач відділу науково-медичної інформації та інтелектуальної власності; юрист-консультант (керівник юридичного відділу університету). До роботи комісії без права участі в голосуванні можуть бути залучені внутрішні чи зовнішні експерти з питань, що розглядаються, представник деканату (декан або заступник декана) особи, справа якої розглядається на засіданні. Головою комісії з питань етики та академічної доброчесності є проректор з наукової роботи. Повноваження щодо підготовки матеріалів до розгляду на засіданні, технічного забезпечення, ведення протоколу засідання здійснює секретар комісії. Рішення про припинення членства внаслідок систематичного невиконання членом комісії своїх обов’ язків чи порушення ним Кодексу академічної етики університету приймається комісією за поданням голови. Рішення вважається прийнятим, якщо його підтримало не менше двох третин від загального складу комісії. Члени комісії не можуть делегувати свої повноваження іншим особам. Виявлення факту академічної недоброчесності у наукових роботах можливе на етапі рецензування та/ 
або представлення вченому секретареві, в редакцію або для розгляду на вченій раді з метою рекомендації до друку - для наукових робіт (монографія, підручник, навчальний посібник, стаття, тези, препринт тощо); на етапі розгляду праць викладачів на засіданні кафедри; на етапі подання на рецензування/перевірку кваліфікаційних робіт [2, 5-7, 9, 12].

Звісно ж, кожен університет самостійно вирішує, чи встановлювати безкоштовне, чи інсталювати комерційне програмне забезпечення [3, 9, 12-14] (Львівський національний медичний університет імені Данила Галицького не є винятком), і ми жодним чином не рекламуємо якогось конкретного провайдера цих послуг чи алгоритми здійснення експертизи. Антиплагіатна експертиза є складовою системи внутрішньоуніверситетського забезпечення якості освітньої діяльності та якості вищої освіти [14-17], «візитною» карткою академічної доброчесності [12, 15-17]. Положення про проведення антиплагіатної експертизи набуває чинності 3 моменту затвердження його наказом [1-3, 8, 12]. Для технічної підтримки перевірки наукових та навчальних праць у методичних вказівках університету розміщуються посилання на сервіси 3 первинної перевірки наукових праць на наявність плагіату [12, 14, 15, 17, 18]. Перевірка наукових робіт здійснюється в мережі «Інтернет» [3, 9, 12, 14], локальних мережах [3, 10-12, 16-18] та репозитарії університету [5, 7, 11, 16, 18]. Репозитарій Львівського національного медичного університету імені Данила Галицького - це інституційний репозитарій відкритого доступу, що акумулює електронні повнотекстові документи наукового та навчально-методичного призначення, створені працівниками будь-якого структурного підрозділу ЛНМУ, аспірантами, магістрантами чи студентами університету, а також надає до них безкоштовний постійний доступ через Інтернет [7].

Кожне антиплагіатне програмне забезпечення (П3), незважаючи на подібність алгоритмів, має свої особливості, переваги та недоліки, особливості пошукової індексації, нюанси щодо зручності та доступності для практичного використання. При проведенні первинної антиплагіатної експертизи документ попередньо трансформується в один із форматів: .doc, .docx, .txt (перевага надається формату .txt) і перевіряється [3, 7, 9, 12-15]. Пошук в Інтернеті здійснюється декількома пошуковими системами [3, 12, 16-18]; візуалізується відсоток оригінальності тексту та список сайтів з відсотком збігу у відповідному кольорі залежно від застосо- ваних пошукових серверів [9, 12]. Положення про первинну експертизу наукових праць на наявність академічного плагіату в Львівському національному медичному університеті імені Данила Галицького визначає основні поняття, завдання, принципи функціонування та призначення [7], склад і структуру [3, 6, 9, 12] та регламентує основні засади організації первинної автоматичної перевірки наукових праць - наукових текстів і дисертаційних матеріалів [1, 2, 6, 8-12]. За об’єктивність висновку про невиявлення академічного плагіату відповідальність несе керівник структурного підрозділу.

Відповідальність за достовірність інформації про дотримання вимог академічної доброчесності, яка подається до вченої ради університету щодо атестації здобувачів [4-6], покладається на проректора 3 наукової роботи [7-9, 12], відповідальну особу за забезпечення діяльності спеціалізованих вчених рад з присудження ступенів доктора філософії та співробітника наукового відділу, відповідального за первинну автоматичну перевірку наукових текстів та дисертаційних матеріалів [7, 12]. У разі подання недостовірної інформації процедура атестації здобувача призупиняється. Повторне подання документів допускається не швидше, ніж через шість місяців [6, 7]. Відповідальна особа за результатами перевірки наукових робіт на факультеті проводить облік, загальний якісний аналіз їх рівня та, відповідно до Закону України «Про авторське право та суміжні права», при необхідності, формує звіт щодо результатів автоматизованої перевірки робіт на плагіат [3, 6, 7, 12, 13]. Відповідальним за первинну антиплагіатну експертизу наукових праць і дисертаційних матеріалів для перевірки дисертаційних праць здобувачів наукового ступеня (зокрема наукового ступеня доктора філософії) функціонує створений (для виконання умов Меморандуму [6] між компанією «Антиплагіат» та Міністерством освіти та науки України від 4 квітня 2018 р.) особистий кабінет в антиплагіатному програмному забезпеченні системи UNICHEK, яка входить до ТОП 20 антиплагіатного ПЗ 2019 р. Перевірка та пошук збігів виконуються по шинглах (методом шингл-розбивки тексту) [3, 7]. Шингл - структурно-логічний фрагмент тексту, що складається 3 послідовності декількох слів) [3, 13]. Пошук в Iнтернеті та репозитарії університету здійснюється декількома ПС, ліцензованим та вільнодоступним ПЗ “Unichek”, “Plagiarism Detector Pro v. 1092” («Детектор плагіату»), “Viper”, “AntiPlagiarism.NET”, “AdvegoPlagiatus” тощо [3, 7, 12]. Перевірка ста- 
тей у фахові журнали та тез доповідей та здійснюється за допомогою ПЗ "Plagiarism Detector Pro", "Viper”, “AntiPlagiarism.NET”, “AdvegoPlagiatus”, при необхідності перевірки англомовних текстів малого об’єму (для швидкої додаткової експертизи тез доповідей, анотацій тощо) - 3 додатковим залученням ресурсів інших інтернет-сервісів [7, 9, 12]. Перевірка дисертаційних робіт та авторефератів проводиться П3 “Unichek", "Plagiarism Detector Pro”, "Viper” [7]. Вибір антиплагіатної програми для проведення перевірки здійснюється індивідуалізовано з урахуванням меморандумів МОН України та методичних рекомендацій [12], обсягу представленого на експертизу матеріалу $[3,9]$, технічних аспектів оптимізації затрат часу та економічних факторів [10, 15-18].
Попереднє (первинне) виявлення плагіату в наукових, навчальних, методичних працях, дисертаційних та кваліфікаційних роботах рекомендовано здійснювати шляхом фахового оцінювання (рецензування, відгуки керівників) із використанням комп’ютерних програм і ресурсів, які знаходяться у вільному доступі, та ліцензійних програм [7, 14, 15, 16, 18]. За 2019 р. здійснено перевірку 2200 наукових та навчально-методичних праць (рис. 1). Відхилено 286 робіт (13 \% загальної вибірки), 3 них 206 тез доповідей (9,36 \% загальної вибірки, 29,86 \% однойменної субвибірки) та 80 статей (відповідно, 3,64 \% загальної вибірки, 6,11 \% однойменної субвибірки). Причинами відхилення були порушення правил цитування та наявність текстових реплікацій.

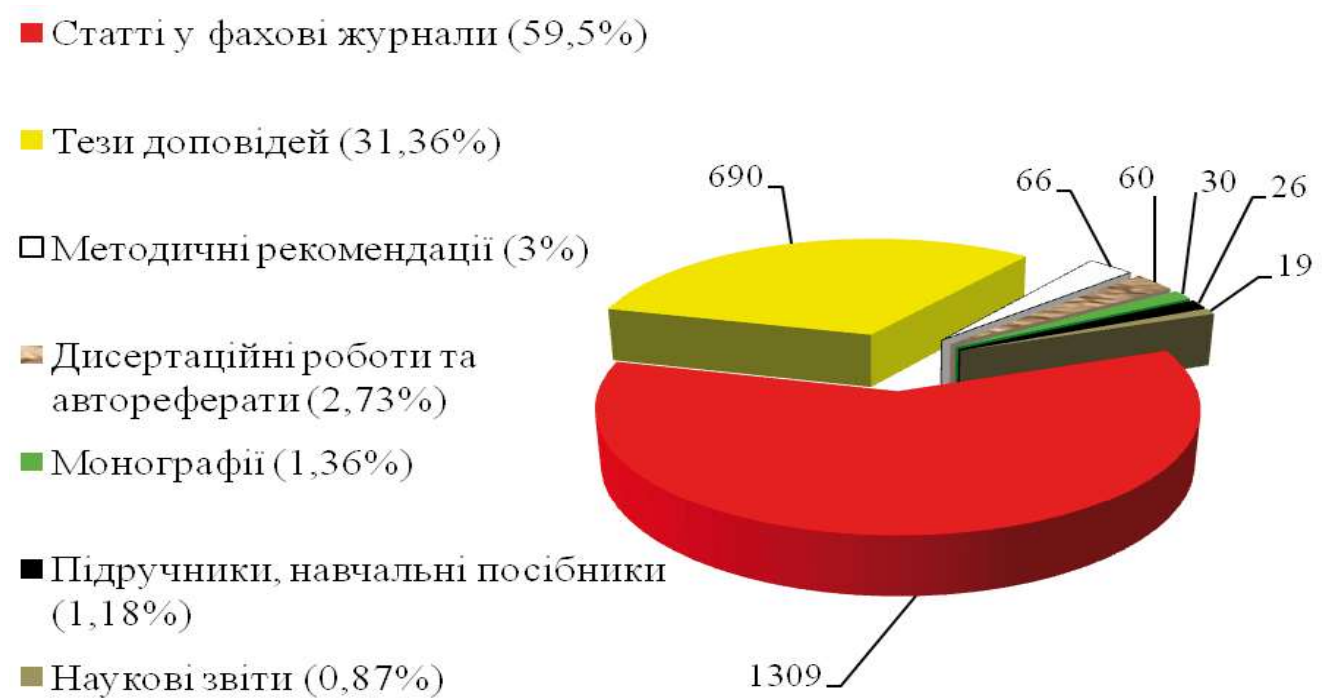

Рис. 1. Первинна антиплагіатна експертиза: розподіл за видами та кількістю перевірених наукових праць у Львівському національному медичному університеті за 2019 р.

За об’єктивність антиплагіатного експертного висновку несе відповідальність керівник відповідного структурного підрозділу [8-12]. Важливим $€$ всебічне і повноцінне ознайомлення науково-педагогічних, наукових та інших працівників і студентів університету з документами [4-7], що детермінують запобігання та встановлюють відповідальність за академічний плагіат [1, 2, 4-7], конкретизують процедуру розгляду апеляцій $[6$, 7]. Виявлення академічного плагіату у захищеній дисертації (науковій доповіді) є абсолютною підставою для скасування рішення спеціалізованої вченої ради про присудження наукового ступеня $[1,2,6,8,11]$. Виявлення плагіату детермінує застосування адміністративних санкцій, проте не може бути стимулом тролінгу чи шантажування на- уковця академічною спільнотою [6, 10, 11, 16-18]. Скасування рішення спеціалізованої вченої ради про присудження наукового ступеня у випадку виявлення академічного плагіату здійснюється у порядку, визначеному Кабінетом Міністрів України, та може бути оскаржене відповідно до чинного законодавства [4, 6, 12, 13]. У випадках наявності встановленого факту академічного плагіату автор сам або за допомогою уповноваженого працівника бібліотеки вилучає роботу з репозитарію [10-12].

Антиплагіатне забезпечення, що встановлене i функціонує у Львівському національному медичному університеті імені Данила Галицького [7], відповідає сучасним критеріям та $є$ адекватним щодо проведення перевірки кириличних та латинськоабеткових наукових текстів. На запит редак- 
цій, які функціонують в університеті, та журналів, регулярно, відповідно до графіків їх роботи, проводиться додатковий фаховий аналіз науководослідних праць щодо їх відповідності критеріям оригінальності тексту [3, 7, 9, 12-14, 16-18]. Для проведення первинної антиплагіатної експертизи на кафедрах та факультетах не рекомендується самостійно користуватися он-лайн антиплагіатними інтернет-ресурсами (надання інформації про проведені дослідження третім, юридично не відповідальним особам, комерційним структурам містить додаткові юридичні ризики) [7, 9, 12]. Здійснюється формування, видання і розповсюдження методичних матеріалів з аспектів академічної доброчесності із вказанням вимог щодо протидії плагіату, належного оформлення посилань на літературні джерела [10,11], впровадження до освітніх програм і навчальних планів підготовки фахівців з вищою освітою окремих курсів і навчальних дисциплін, що забезпечують формування та дотримання етичних принципів [1, 2, 5-8], коректного менеджменту інформації при роботі з первинними та вторинними інформаційними ресурсами [13, 14, 16-18] та об'єктами інтелектуальної власності [2, 10-12, 1517]; розміщення на веб-сайтах періодичних видань університету викладу етичних норм публікації та рецензування статей, інших наукових і навчальнометодичних матеріалів.

Висновки та перспективи подальших досліджень. 1. Академічна доброчесність та уніфікація контролю якості стимулюють зростання соціальної та професійної мобільності, пошук нових партнерів для фінансування вищої освіти, посилення диверсифікації вищої освіти в більшості країн, нову структуру виробництва наукового знання, постійне зростання цінності проблемно-орієнтованого знання, його трансдисциплінарний характер. Послідовність заходів у разі виявлення проявів академічної недоброчесності з боку здобувачів, викладачів і дослідників є похідною Кодексу академічної етики, що визначає основні поняття, завдання, принципи функціонування та призначення, склад і структуру та регламентує основні засади організації первинної автоматичної перевірки наукових праць (наукові

\section{Список літератури}

1. Академічна доброчесність. Державний університет інфраструктури та технологій. - 2020. - URL : https:// duit.edu.ua/educational-activities/academic-virtue.

2. Академічна чесність як основа сталого розвитку університету / Міжнародний благодійний Фонд «Міжнародний фонд дослідження освітньої політики» ; за звіти, монографії, статті, тези тощо), відповідно до рекомендацій Асоціації європейських університетів щодо відкритого доступу до інформації, міжнародних асоціацій, законодавства України, базується на Законі України «Про вищу освіту» щодо забезпечення відкритого безкоштовного Інтернет-доступу до наукових та навчально-методичних ресурсів.

2. Попереднє (первинне) виявлення плагіату в наукових роботах здійснюється шляхом експертної оцінки (рецензування), використання комп’ютерних програм, залучення університетського репозитарію, вільнодоступних інтернетсайтів та інших ресурсів. Для технічної підтримки перевірки наукових праць на наявність академічного плагіату в методичних вказівках університету розміщується посилання на сервіси з первинної перевірки на наявність плагіату. Перевірка та пошук збігів виконуються по шинглах (методом шинглрозбивки тексту) ліцензованим програмним забезпеченням «Детектор плагіату», “Viper”, “Unichek”, “AntiPlagiarism.NET” тощо, з додатковим залученням (при необхідності швидкої додаткової експертизи англомовних текстів малого об’єму) ресурсів інших інтернет-сервісів.

3. Антиплагіатна експертиза як складова академічної доброчесності в Львівському національному медичному університеті включає комплекс заходів з метою: забезпечення збереження авторських прав шляхом проведення перевірки наукових робіт (наукові звіти, монографії, статті, тези тощо) на плагіат до процедури їх публікації (захисту); формування та розвитку бази даних та електроного репозитарію як джерела забезпечення вільного доступу до наукових матеріалів для сприяння підвищенню престижу університету; покращення якості освіти, підвищення продуктивності навчального процесу та дослідницької діяльності.

Перспективою подальших досліджень є продовження аналізу ефективності сучасного програмного забезпечення щодо можливостей застосування в контексті перехресної антиплагіатної перевірки наукових праць для досягнення максимальної валідності результатів експертизи.

заг. ред. Т. В. Фінікова, А. Є. Артюхова. - К. : Таксон, 2016. - 234 c

3. Вергун А. Р. Програмне забезпечення для перевірки наукових текстів на плагіат : інформаційний огляд / А. Р. Вергун, Л. В. Савенкова, С. О. Чуканова. - К., 2016. - 37 c. 
4. Закон України «Про вищу освіту» від 1 липня 2014 poкy № 1556-VII. - URL : http://osvita.ua/legislation/ law/2235.

5. Кодекс академічної етики Львівського національного медичного університету імені Данила Галицького. - 2020. - URL : http://nauka.meduniv.lviv.ua/wp-content/ uploads/2020/04/kodeks-akademichnoyi-etiki.pdf.

6. Лист Міністерства освіти і науки України від 23.10.2018 р. № 1/9-650 «Керівникам закладів вищої освіти щодо рекомендацій з академічної доброчесності для закладів вищої освіти». - URL : https://zakononline. com.ua/documents/show/124272_ 124272.

7. Положення про первинну експертизу наукових праць на наявність академічного плагіату в Львівському національному медичному університеті імені Данила Галицького. - 2020. - URL : http://nauka.meduniv.lviv. ua/wp-content/uploads/2020/03/nove_polozhennya_pro_ ekspertizu_2020.pdf.

8. Семінар кураторів щодо шляхів популяризації академічної доброчесності на факультеті АТЕ. Таврійський державний агротехнологічний університет імені Дмитра Моторного. - 2020. - URL : http://www.tsatu. edu.ua/seminar-kuratoriv-schodo-shljahiv-populjaryzacijiakademichnoji-dobrochesnosti-na-fakulteti-ate.

9. Хобзей М. К. Деякі аспекти первинної експертизи наукових праць на наявність академічного плагіату / М. К. Хобзей, А. Р. Вергун // Медична освіта. - 2016. № 3 (71). - С. 102-105.

\section{References}

1. (2020). Akademichna dobrochesnist [Academic integrity]. State University of Infrastructure and Technology. Retrieved from: https //duit.edu.ua/educational-activities/ academic-virtue [in Ukrainian].

2. Finikova, T.V., \& Artyukhova, A.Ye. (Eds.) (2016). Akademichna chesnist yak osnova staloho rozvytku universytetu [Academic honesty as a basis for sustainable development of the university]. Mizhnarodnyi blahodiinyi Fond "Mizhnarodnyi fond doslidzhennia osvitnioi polityky" - International Charitable Foundation "International Fund for Educational Policy Research”. Kyiv: Takson [in Ukrainian].

3. Verhun, A.R., Savenkova, L.V., \& Chukanova, S.O. (2016). Prohramne zabezpechennia dlia perevirky naukovykh tekstiv na plahiat. Informatsiynyy ohliad [Software for checking scientific texts on plagiarism. Information review]. Kyiv [in Ukrainian].

4. (2014). Zakon Ukrainy «Pro vyshchu osvitu» 1 lypnia 2014 roku № 1556-VII [Law of Ukraine “On Higher Education” July 1, 2014 No. 1556-VII]. Retrieved from: http:// osvita.ua/legislation/law/2235 [in Ukrainian].

5. (2020). Kodeks akademichnoi etyky Lvivskoho natsionalnoho medychnoho universytetu imeni Danyla Halytskoho [Code of Academic Ethics of Danylo Halytskyi Lviv National Medical University]. Retrieved from: http://nauka.
10. Хоружий Г. Ф. Європейська політика вищої освіти : монографія / Г. Ф. Хоружий. - Полтава : Дивосвіт, 2016. - 384 c.

11. Центральна наукова бібліотека. Харківський національний університет імені В. Н. Каразіна. - 2020. - URL : https://www.univer.kharkov.ua/ua/general/structure/library.

12. Чоп’як В. В. Технічна експертиза наукових праць на наявність академічного плагіату / В. В. Чоп'як, О. Б. Надрага, А. Р. Вергун. - Львів : Вид-во ЛНМУ ім. Данила Галицького, 2016. - 49 с.

13. Шишка Р. Б. Плагіат та його прояви і небезпеки / Р. Б. Шишка // Часопис Київського університету права. - 2014. - № 4. - С. 170-176.

14. Academic Plagiarism. - 2020. - URL : http://www. academicplagiarism.com.

15. Andreescu L. Self-plagiarism in academic publishing: the anatomy of a misnomer / L. Andreescu // Sci. Eng. Ethics. - 2013. - Vol. 19 (3). - P. 775-797.

16. Li Y. Text-based plagiarism in scientific writing: what Chinese supervisors think about copying and how to reduce it in stu-dents' writing / Y. Li // Sci. Eng. Ethics. - 2013. Vol. 19 (2). - P. 569-583.

17. Medical student plagiarism in problem-based learning courses / K.-J. Kim, J.-Y. Hwang, D.-W. Lee, M.-S. Shim // Medical Education Online. - 2016. - Vol. 21 (1). - P. 30537.

18. Plagiarism in medical scientific research / R. A. A. Mohammed, O. M. Shaaban, D. G. Mahran [et al.] // J. Taibah University Med. Sci. - 2015. - Vol. 10 (1). P. 6-11.

meduniv.lviv.ua/wp-content/uploads/2020/04/kodeksakademichnoyi-etiki.pdf [in Ukrainian].

6. Lyst Ministerstva osvity i nauky Ukrainy vid 23.10.2018 № 1/9-650 «Kerivnykam zakladiv vyshchoi osvity shchodo rekomendatsii z akademichnoi dobrochesnosti dlia zakladiv vyshchoi osvity» [Letter of the Ministry of Education and Science of Ukraine dated 23.10.2018 № 1 / 9-650 “To the heads of higher education institutions on recommendations on academic integrity for higher education institutions"]. Retrieved from: https://zakononline.com.ua/documents/ show/124272_124272 [in Ukrainian].

7. (2020). Polozhennia pro pervynnu ekspertyzu naukovykh prats na naiavnis akademichnoho plahiatu $v$ Lvivskomu natsionalnomu medychnomu universyteti imeni Danyla Halytskoho [Regulations on the initial examination of scientific papers for the presence of academic plagiarism at the Lviv National Medical University named after Danylo Halytskyi]. Retrieved from: http://nauka.meduniv. lviv.ua/wp-content/uploads/2020/03/nove_polozhennya_ pro_ekspertizu_2020.pdf [in Ukrainian].

8. (2020). Seminar kuratoriv shchodo shliakhiv populiaryzatsii akademichnoi dobrochesnosti na fakulteti ATE [Seminar of curators on ways to promote academic integrity at the Faculty of ATE]. Tavriiskyi derzhavnyi 
ahrotekhnolohichnyi universytet imeni Dmytra Motornoho. Retrieved from: http://www.tsatu.edu.ua/seminarkuratoriv-schodo-shljahiv-populjaryzaciji-akademichnojidobrochesnosti-na-fakulteti-ate [in Ukrainian].

9. Khobzey, M.K., \& Verhun, A.R. (2016). Deiaki aspekty pervynnoi ekspertyzy naukovykh prats na naiavnist akademichnoho plahiatu [Some aspects of the initial examination of scientific papers on the presence of academic plagiarism]. Medychna osvita - Medical Education, 3 (71), 102-105 [in Ukrainian].

10. Khoruzhyy, H.F. (2016). Yevropeiska polityka vyshchoi osvity. Monohrafiia [Khoruzhiy GF European policy of higher education. Monograph]. Poltava: Dyvosvit [in Ukrainian].

11. (2020). Tsentralna naukova biblioteka. Kharkivskyi natsionalnyi universytet imeni V. N. Karazina [Central Scientific Library. V.N. Karazin Kharkiv National University]. Retrieved from: https://www.univer.kharkov.ua/ua/general/ structure/library [in Ukrainian].

12. Chopiak, V.V., Nadraha, O.B., \& Verhun, A.R. (2016). Tekhnichna ekspertyza naukovykh prats na naiavnist akademichnoho plahiatu [Technical examination of scientific works on the presence of academic plagiarism]. Lviv: Vyd-vo LNMU im. Danyla Halytskoho [in Ukrainian]. 13. Shyshka, R.B. (2014). Plahiat ta yoho proiavy i nebezpeky [Plagiarism and its manifestations and dangers]. Chasopys Kyivskoho universytetu prava - Journal of Kyiv University of Law, 4, 170-176 [in Ukrainian].

14. (2020). Academic Plagiarism. Retrieved from: http:// www.academicplagiarism.com.

15. Andreescu, L. (2013). Self-plagiarism in academic publishing: the anatomy of a misnomer. Sci. Eng. Ethics., 19 (3), 775e797.

16. Li, Y. (2013). Text-based plagiarism in scientific writing: what Chinese supervisors think about copying and how to reduce it in stu-dents' writing. Sci. Eng. Ethics, 19 (2), 569-583.

17. Kim, K.-J., Hwang, J.-Y., Lee, D.-W., \& Shim, M.-S. (2016). Medical student plagiarism in problem-based learning courses. Medical Education Online, 21 (1), 30537.

18. Mohammed, R.A.A., Shaaban, O.M., Mahran, D.G., Attellawy, H.N., Makhlof, A., \& Albasri, A. (2015). Plagiarism in medical scientific research. J. Taibah University Med. Sci., 10 (1), 6-11. 